\title{
International Cooperation among Tertiary Educational Institutions: Trends and Prospects
}

\author{
Mariia M. Kiselova ${ }^{1}$, Oksana A. Hudovsek ${ }^{2}$, Svitlana V. Bykova ${ }^{3}$, Oleksandra O. Tsybanyk ${ }^{4}$, Alla I. Chagovets ${ }^{5}$ \\ ${ }^{1}$ Department of Pediatrics and Neonatology, Faculty of Postgraduate Education, Danylo Halytsky National Medical \\ University, Lviv, Ukraine \\ ${ }^{2}$ Department of Primary Education Pedagogy, Faculty of Pedagogy, Rivne State University of Humanities, Rivne, \\ Ukraine \\ ${ }^{3}$ Department of Philosophy, Political Sciences, Psychology and Law, Odessa State Academy of Civil Engineering \\ and Architecture, Odessa, Ukraine \\ ${ }^{4}$ Department of Theory and Methods of Physical Education, College of Physical Culture and Public Health, Yuriy \\ Fedkovych Chernivtsi National University, Chernivtsi, Ukraine \\ ${ }^{5}$ Department of Theory and Methods of Preschool Education, Faculty of Preschool and Special Education and \\ History, Municipal Establishment "Kharkiv Humanitarian Pedagogical Academy” of Kharkiv Regional Council, \\ Kharkiv, Ukraine \\ Correspondence: Mariia M. Kiselova, Danylo Halytsky National Medical University, 69 Pekarska str., Lviv, 79010 , \\ Ukraine.
}

Received: June 10, 2020

Accepted: August 3, 2020

Online Published: August 10, 2020

doi:10.5430/ijhe.v9n7p356

URL: https://doi.org/10.5430/ijhe.v9n7p356

\begin{abstract}
Within the conditions of rapid development of internationalization processes, the scale of international cooperation between tertiary educational institutions is growing at a quick rate. Currently, the practice of international cooperation between tertiary educational institutions is the most commonly encountered in the form of: international exchange of apllicants of tertiary education (students), teachers (educators), scientists; holding conferences, round tables, symposiums; exchange of information and data on improving the efficiency of the educational process. Therefore, the list of the above mentioned types of international cooperation between tertiary educational institutions is not exhaustive and is constantly updated. Based on the foregoing, the aim of the scientific article is to study the theoretical and practical aspects of international cooperation among tertiary educational institutions in the framework of determining current trends and future prospects for the development of such relations. Methods of analysis, synthesis, observation, description and comparison have been used to disclosure the theoretical and practical aspects of international cooperation among tertiary educational institutions in the framework of determining current trends and future prospects for the development of such relations. The scientific article has discussed and analyzed the dynamics of the students' mobility from abroad, enrolled in tertiary education, as well as the level of students' mobility in areas of the corresponding level of higher education in such countries, as: Germany, the Czech Republic and Sweden. The peculiarities of the functioning of the following international networks and university wide projects and platforms have been determined, namely: ACCESS, CALIE, European University Association, Eutopia, Inspireurope, International Association of Universities, MIRAI, Nordic Association of University Administrators, Nordic Centre India, Nordic Centre Fudan University, Nordic Institute of Asian Studies, SGroup European Universities' Network, SANORD, Scholars at risk, SASUF, which have been formed as a result of international cooperation among tertiary educational institutions. According to the data of the European University Association, it has been established that tertiary educational institutions of Ukraine also take an active part in the system of international cooperation. For instance, 26 tertiary educational institutions of Ukraine act as Individual Full Members and Individual Associate Members of the European University Association. It has been established that the basic areas of international cooperation among tertiary educational institutions include: the development of international mobility in the framework of the exchange not only of students, but also of educators, researchers, and administrative staff; joint teaching and investigation activities; research cooperation.
\end{abstract}

Keywords: international cooperation, internationalization, international network, tertiary educational institutions (TEI) 


\section{Introduction}

Despite the rapid spread of education around the world, industrialized countries are decades ahead of developing countries in terms of knowledge acquisition. Within the conditions of rapid development of internationalization processes, the scale of international cooperation between tertiary educational institutions is growing at a quick rate. Currently, the practice of international cooperation between tertiary educational institutions is the most commonly encountered in the form of: international exchange of apllicants of tertiary education (students), teachers (educators), scientists; holding conferences, round tables, symposiums; exchange of information and data on improving the efficiency of the educational process. Therefore, the list of the above mentioned types of international cooperation between tertiary educational institutions is not exhaustive and is constantly updated.

Taking in consideration the above, the relevance of the subject matter of the scientific article is to identify key aspects of international cooperation among tertiary educational institutions (on the example of practical experience of international cooperation of tertiary educational institutions in Germany, the Czech Republic, Sweden and Ukraine).

The purpose of the academic paper is to study the features of international cooperation between tertiary educational institutions and identify future trends of cooperation.

In accordance with the purpose outlined, the basic objectives of the study have been defined, namely:

1. To identify differences in international cooperation between tertiary educational institutions within EU countries on the example of Germany, the Czech Republic and Sweden.

2. To identify future trends in international cooperation between tertiary educational institutions in advanced countries.

\section{Literature Review}

"International cooperation is a form of cooperation that happens between countries in order to fulfil the people's need". "Consortia of Higher Education Institutions have been a global reality since the last decades of the twentieth century" (Beerkens, 2018). Forms of international cooperation have significantly expanded and include "technology, such as laboratory, e-library, online learning system, computerized student data, etc." (Beerkens, 2018). Therefore, developing countries cooperate with advanced countries in order to integrate such forms of education.

Another reason for international cooperation is the imbalance between developing countries and advanced countries in terms of training (organization, lack of quality research, low-quality training programs in developing countries; the need for quality labor and talents of advanced countries). This leads to the emergence of the concept of students' mobility, which is a tool for solving these problems and the imbalance between countries. The use of the concept of mobility is possible under the condition of effective legal regulation (Bonilla, Salles-Filho \& Bin, 2018).

The third problem of international cooperation lies in obstacles to universities' cooperation in terms of research and development (Franco \& Pinho, 2019). At the same time, the exchange of experience and knowledge is recognized at the international level as a priority and a reason for international cooperation (Skvorcovs, Titareva \& Igors, 2018). Transmission, transfer of knowledge, choice of partners and the possibility of funding research projects stimulate types of cooperation between universities, and cultural differences between researchers and research centers are an advantage of cooperation (Galan et al., 2018).

Analysis of theoretical aspects of international cooperation among tertiary educational institutions in the framework of determining current trends and future prospects for the development of such relations requires a review of a number of studies conducted by Ukrainian and foreign scholars in this field.

Based on the above, it should be noted that Franco and Pinho (2019) study the interaction features of the universities, conducting research activities in the context of identifying promising areas of knowledge transfer. Scholars contend that cooperation among universities should be viewed through the prism of knowledge transfer, culture, financing and choice of partners.

Donchenko (2015) notes that the formation of international partnerships is an important element in the internationalization of the tertiary education system. Thus, international partnerships increase the institutional development of tertiary educational institutions, the level of innovation and research, improve the quality of educational services, as well as create appropriate conditions for the exchange of resources.

Herewith, Oganesyan (2017) in his own study considers new forms of international cooperation between tertiary educational institutions and concludes that currently more developed systems of tertiary educational institutions are 
rapidly integrated into the system of international networks and, thus, create a networked institution of tertiary education.

Obolenska and Tsyrkun (2016), studying the issues of international cooperation among tertiary educational institutions, claim that the introduction of accredited curricula in the educational process is carried out, taking into account current trends in the internationalization of tertiary education.

Herewith, King (2009) considers the role of academic cooperation in the framework of international collaboration among tertiary educational institutions and states that external factors have a significant impact on such processes.

Chetro-Szivos (2010) notes that: "international partnerships between universities can instill in future leaders the values and knowledge to build a sustainable future". In addition, the researcher emphasizes that international cooperation between tertiary educational institutions involves the internationalization of tertiary education. Various projects of cooperation between tertiary educational institutions regarding development and academic exchange are also developed and implemented in practice within the framework of international cooperation.

The team of scholars (Arcella, Mincer-Daszkiewicz \& Ravaioli, 2009), in the context of studying the issues of international cooperation between tertiary educational institutions, state that the most optimal way to obtain information on the principles and features of international cooperation between tertiary educational institutions, as well as data on the status and level of mobility between them, is to participate in the processes taking place in the IRO system, specially designed for cooperating of tertiary educational institutions.

Kerimbayev, Kultan, Abdykarimova and Akramova (2017) note that in the framework of international cooperation between tertiary educational institutions, applicants (students) have the opportunity to obtain distance international education through LMS Moodle. According to the provisions of this system, the primary stage of obtaining distance international education centers around the preparation of educational materials, structure and content of lectures, seminars and practical classes, as well as educators for distance learning. As a result, after passing the particular exam, the student obtains the document on distance international education.

\section{Data and Methods}

The study is based on a qualitative methodology: "A qualitative approach was adopted, and within this the case study method" (Franco \& Pinho, 2019). Methods of analysis, observation, description and comparison have been used to disclosure the theoretical and practical aspects of international cooperation among tertiary educational institutions in the framework of determining current trends and future prospects for the development of such relations.

The study is based on a meta-analysis of publications (Wolf, 1986), data of Eurostat (n.d.) and tertiary educational institutions of Germany, the Czech Republic and Sweden. In order to identify trends in the training at TEI, the following data have been used, namely:

1) Dynamics of students' mobility from abroad, enrolled in tertiary education for the period of 2014-2017,

2) Number of students, enrolled in tertiary education in 2017, according to the level of tertiary education,

3) Number of students, enrolled in tertiary education in 2014, according to the level of tertiary education.

The methodological basis of the academic paper is based on data and research of the European Commission, Central European University, European University Association, Eurostat, Polish National Agency for Academic Exchange, Palacký University, UNESCO, Warsaw University of Technology, the University of Gothenburg, QS.

\section{Results}

In the course of the study it has been established that international cooperation among tertiary educational institutions is based on the relevant guide lines and principles.

According to the Agreement of Cooperation between Universities approved by the Association of Accredited Public Policy Advocates to the European Union, cooperation among tertiary educational institutions is carried out in the following directions:

1) institutional exchange in the framework of attracting educators and staff of tertiary educational institutions to participate in various activities of teaching, research or professional nature;

2) involvement of students in the educational process of the certain higher educational establishment - the partner of other tertiary educational institutions for the relevant educational period, in order to provide students with educational experience, while ensuring proper living conditions and accommodation facilities for students at the expense of the tertiary educational institution; 
3) organization and holding of conferences, symposia, forums, trainings, etc.;

4) exchange of information on the prospects of the educational process development, students' progress as individuals, researches conducted at tertiary educational institutions;

5) ensuring proper conditions for academic cooperation among faculties and among post-graduate students of tertiary educational institutions;

6) planning and coordination of all activities in respect of which cooperation between partners - tertiary educational institutions is envisaged;

7) provision the availability of information concerning the activities of the tertiary educational institution, in particular about the areas of research, educational resources, library stock;

8) provision of periodic meetings of representatives of tertiary educational institutions within the framework of search for new more promising areas of further cooperation (Association of Accredited Public Policy Advocates to the European Union, 2019).

In addition to the Agreement of Cooperation between Universities, other regulations and documents governing the principles of international cooperation between tertiary educational institutions are as follows: 1) a memorandum of understanding (concluded for a maximum of 3 years); 2) bilateral agreement between tertiary educational institutions (in most cases concluded in 2 stages) (Central European University, n.d).

As part of the promotion of international cooperation between tertiary educational institutions, European Commission has developed and implemented special programs, such as Erasmus + and Horizon 2020, which support the international exchange of teachers, students and researchers. In addition, the above mentioned programs also aim to ensure structured cooperation between tertiary educational institutions and public authorities. For example, in 2014, all countries of the world gained access to the Erasmus + program. According to this program, regional cooperation of tertiary educational institutions of European Union member states with universities of other countries of the world is envisaged in the context of promoting poverty reduction and increasing the level of inclusive education. In addition, the Erasmus + program provides support to the curricula of tertiary educational institutions, which is necessary to improve the quality of teaching and achieve the appropriate level of the educational process (European Commission, n.d.a; n.d.b).

It should be noted that the Bologna Process has been developed and put into practice in order to ensure the internationalization of tertiary education. The basic goal of the Bologna Process is to achieve coherence between tertiary educational systems in 48 European countries. The Bologna Process also promotes the mobility of teachers and students, as it aims to ensure greater accessibility and inclusion at tertiary educational institutions (European Commission, n.d.d).

It should also be noted that European Commission (n.d.c) is also actively cooperating with countries that are not members of European Union in the framework of internationalization of national tertiary education and training systems.

Along with this, Orosz and Craciun (2019) highlight a number of benefits of international cooperation between tertiary educational institutions. In particular, according to researchers' viewpoints, international cooperation makes it possible:

1) to strengthen the institutional academic and administrative capacity of tertiary educational institutions;

2) to improve the quality of tertiary education;

3) to increase the efficiency level of the tertiary education system;

4) to improve the quality and increase the amount of human capital;

5 ) to increase the prestige of tertiary educational institutions in the international arena;

6) to expand the participation of students and teachers in international exchange processes or in joint research projects;

7) to improve students' performance;

8) to raise the level of intercultural awareness, etc.

The experience of European Union concerning international cooperation in tertiary education shows the annual growth of the international academic network between the member states of European Union and other countries. At the same time, European Union promotes cooperation between tertiary educational institutions of European Union 
Member States and other countries. The basic aspect of international cooperation between tertiary educational institutions is aimed at: 1) attracting talented individuals to the structure of tertiary education in European Union Member States; 2) support for innovation and creation of job opportunities through a skills mobility system; 3) support for the policy of European Union, in particular in the field of enlargement, international development, international migration, intercultural dialogue(European Commission, n.d.c).

Based on the foregoing, special attention should be given to consideration and analysis of the practical experience of international cooperation among tertiary educational institutions on the example of such European countries as Germany, the Czech Republic and Sweden.

Taking this into account, it should be noted that in the period of 2014-2017 tendentious increase in the mobility of students from abroad in all three studied countries was observed, in particular, the most significant growth was revealed in Germany, where in 2017 compared to 2014 the increase was 23,00\% (Table 1). In contrast to Germany, in Sweden the increase was much lower (13,35\%), and in the Czech Republic - even lower (7,56\%).

Table 1. Dynamics of students' mobility from abroad, enrolled in tertiary education

\begin{tabular}{lcccc}
\hline Region & $\mathbf{2 0 1 4}$ & $\mathbf{2 0 1 5}$ & $\mathbf{2 0 1 6}$ & $\mathbf{2 0 1 7}$ \\
\hline Total for EU & n.a. & n.a. & 1206815 & n.a. \\
Member States & & & & 244575 \\
Germany & 210542 & 228756 & 42812 & 258873 \\
The Czech & 41150 & 41715 & & 44261 \\
$\begin{array}{l}\text { Republic } \\
\text { Sweden }\end{array}$ & 25361 & 26625 & 28029 & 28747
\end{tabular}

Source: Eurostat (n.d.)

Regarding the affiliation of students, studying at tertiary educational institutions, to the appropriate level of education, as evidenced by the data of Figure 1 and Figure 2, the highest level of mobility among students in both Germany and Sweden, was focused on the direction of obtaining Master's degree or equivalent level degree. In the Czech Republic, on the other hand, the highest level of mobility among students was concentrated in the direction of obtaining Bachelor's degree equivalent level degree.

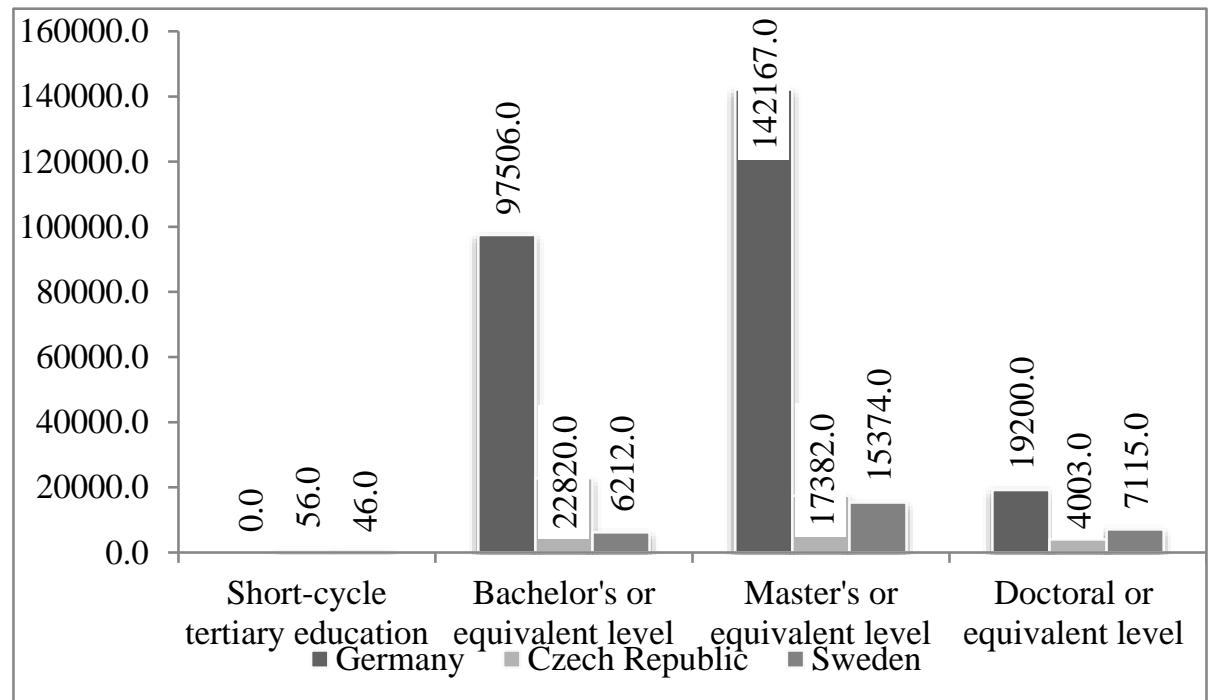

Figure 1. Number of students, enrolled in tertiary education in 2017, according to the level of tertiary education Source: Eurostat (n.d.) 


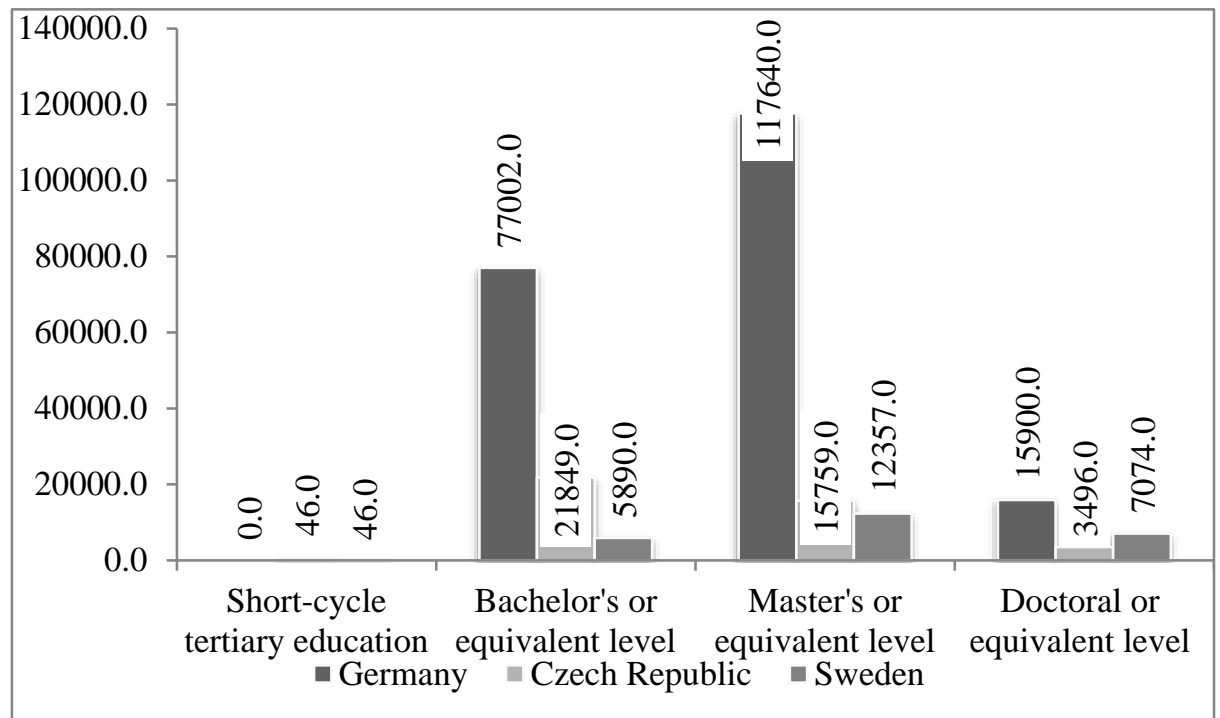

Figure 2. Number of students, enrolled in tertiary education in 2014, according to the level of tertiary education Source: Eurostat (n.d.)

As a rule, international cooperation among tertiary educational institutions is prevalently approved on the basis of three short-term agreements, concluded in advance. Such agreements are as follows: Confidentiality Agreement, a Memorandum of Understanding and an Exclusivity Agreement. The Agreement on International Cooperation between Universities defines the conditions and obligations of the participants in this agreement - tertiary educational institutions (Association of Accredited Public Policy Advocates to European Union, 2019).

In the course of the study it has been found that in the framework of international cooperation, tertiary educational institutions try to attract students from all over the world, forasmuch as such actions will strengthen the process of internationalization. Tertiary educational institutions try to attract students by the method of proposal, giving domestic students the opportunity to travel abroad as a result of exchange programs, as well as providing professional training in accordance with the needs of potential employers. Tertiary educational institutions can also confer competitive advantages by funding various cross-cultural university partnerships, forasmuch as they will increase the level of academic and scientific development of tertiary educational institutions, as well as create opportunities for the exchange of not only students, but also educators in the framework of specially designed and existing programs (Quacquarelli Symonds (QS), 2019).

For instance, in Germany, international cooperation among tertiary educational institutions is treated as an important element of training and research practice. Also, German scholars believe that international cooperation among tertiary educational institutions improves intercultural skills not only of students but also of educators. And this, in turn, will promote tertiary educational institutions among other establishments of the world tertiary education system (International university partnerships, n.d.).

According to the data of German Rectors' Conference, currently more than 33,000 agreements have been concluded among German tertiary educational institutions (approximately 300 German tertiary educational institutions) and partner institutions (almost 5400) in more than 150 countries (International university partnerships, n.d.).

Taking this into consideration, the basic types of cooperation among German tertiary educational institutions and partner institutions (mainly with universities, less often with extra-university institutions) are as follows:

1) ensuring the development of international mobility in the framework of the exchange of students and educators (mainly, Doctors of Science), researchers and administrative staff;

2) ensuring international cooperation in teaching activities through mutual confirmation of achievements in science and curricula;

3) provision of international research cooperation, in particular, in the field of research projects' development, holding joint conferences, publishing joint scientific papers;

4) provision of international cooperation in the field of institutional development of tertiary educational institutions by a process of staff exchange, as well as through automatic assessment of institutional development or through 
cooperation between computer centers and libraries of tertiary educational institutions (International university partnerships, n.d.).

The University of Gothenburg is a conspicuous example of international cooperation among tertiary educational institutions in Sweden. This university is actively involved in international cooperation with partner institutions in the direction of development and implementation of joint projects. As of today, the University of Gothenburg has already concluded more than 1100 student exchange agreements and is actively accepting international students for studying from about 70 countries of the world (nationalities) (University of Gothenburg, n.d.).

It should be noted that currently the University of Gothenburg is a member of numerous international networks and university wide projects and platforms, including (University of Gothenburg, n.d.):

- ACCESS (a joint project of international cooperation between tertiary educational institutions in Sweden and Chile, designed to establish and support relations among research scientists, educators and students of tertiary educational institutions of these countries in the framework of solving a number of universal problems);

- CALIE (Project for Collaboration, Academic Leadership \& Innovation in Higher Education) (a joint project of international cooperation among tertiary educational institutions of Sweden (University of Gothenburg, Lund University, Uppsala University and Stockholm University) and the United States (Stanford University, the University of Washington and the University of California at Berkeley), targeted at updating of education through innovation and academic leadership);

- European University Association (EUA) (an organization that supports more than 850 tertiary educational institutions in 47 countries in the direction of provision networks and information concerning the latest trends in research activities and tertiary education);

- $\quad$ Eutopia (international union, created by the Belgian Vrije Universiteit Brussel, the French University CY Cergy Paris, the British University of Warwick, the Slovenian University of Ljubljana, the University of Gothenburg, and the Spanish University Pompeu Fabra in Barcelona, in order to form an alliance of European institutions for strategic cooperation at the request of the European Commission);

- Inspireurope (a project of international cooperation among 10 European tertiary educational institutions, designed to support researchers, whose lives or careers are at risk from harassment, discrimination or violence);

- International Association of Universities (IAU) (an organization created on the basis of UNESCO with the purpose of promoting the principles of freedom, justice, solidarity and human dignity through a system of tertiary educational institutions in 120 countries of the world);

- $\quad$ MIRAI (a project established by 7 Swedish tertiary educational institutions and 8 Japanese tertiary educational institutions, aimed to support researchers who are in the early research stages);

- Nordic Association of University Administrators (NUAS) (an international organization that carries out activities in order to strengthen relationships and establish networks among tertiary educational institutions in the North (Nordic universities));

- $\quad$ Nordic Centre India (NCI) (an international concilium, which includes 20 well-known northern tertiary educational institutions, interested in cooperation with universities in India and Southeast Asia in the direction of research activities and tertiary education);

- Nordic Centre Fudan University (an international network of 24 northern tertiary educational institutions, which also includes Fudan University and the Nordic Institute of Asian Studies. It operates to ensure the development of educational and research activities);

- Nordic Institute of Asian Studies (NIAS) (research and service institute of North Asia, which operates to carry out economic, social, political, cultural and business transformations in Asia, based on the historical aspects of this territory);

- $\quad$ SGroup European Universities' Network (an international network of 34 European tertiary educational institutions in 15 European countries, which operates to strengthen internationalization through the use of benchmarking and the implementation of joint projects);

- SANORD (international network of tertiary education and research activitiesthat operates to promote strategic international academic cooperation among tertiary educational institutions of the Northern and Southern African regions);

- Scholars at risk (SAR) (an international network of tertiary educational institutions and individuals that operates to promote academic freedom and protect the rights of scientists in all countries of the world);

- SASUF (a project of international cooperation between 13 tertiary educational institutions of Sweden and 23 tertiary educational institutions of South Africa, created to strengthen relations among the countries in the field 
of research activities, innovation, education in accordance with the goals of sustainable development approved by the UN).

Based on the processing of information, submitted by the European University Association (EUA), 24 tertiary educational institutions of Ukraine are Individual Full Members of the EUA, namely: Borys Grinchenko Kyiv University, Bukovinian State Medical University, Donetsk National University (DonNU), Donetsk National University of Economics and Trade named after Mykhailo Tugan-Baranovsky, Lviv Polytechnic National University, National Pedagogical Dragomanov University, National Technical University "Kharkiv Polytechnic Institute", National University "Odessa Law Academy", National University of Kyiv-Mohyla Academy, National University of Life and Environmental Sciences of Ukraine, Odessa National Academy of Food Technologies, Odessa National I.I. Mechnikov University, Odessa National Maritime University, Odessa National Polytechnic University, State University "Uzhhorod National University", Sumy State University, Taras Shevchenko National University of Kyiv, Ternopil Ivan Puluj National Technical University, Ternopil National Economic University, Ukrainian Medical Stomatological Academy, V.N. Karazin Kharkiv National University, Vasyl Stefanyk Precarpathian National University, Vinnytsia National Technical University, Yaroslav Mudryi National Law University. At the same time, Alfred Nobel University and I. Horbachevsky Ternopil National Medical University are the Individual Associate Members (European University Association, n.d.).

In the context of studying the practical aspects of international cooperation among tertiary educational institutions, attention should be paid to such sphere as physical education. For example, in the Czech Republic, Palacký University, in particular one of the faculties of this university actively conducts international cooperation in the field of development and support of physical education (Palacký University Olomouc, n.d.).

It should be noted that various programs are developed and implemented within the framework of international academic partnerships between tertiary educational institutions. For example, Polish National Agency for Academic Exchange (Poland) has developed a program that provides cooperation between international academic partnerships in the framework of scientific and educational development of partnership members (Polish National Agency for Academic Exchange, n.d.).

United Nations Educational, Scientific and Cultural Organization has also developed a program that provides inter-university international cooperation between tertiary educational institutions. As a result of the implementation of this program, the management is carried out by a specially created Section for International Cooperation in Higher Education. The basic competences of this section include solving the problems of capacity building and expansion of knowledge that are necessary in the educational and scientific process. At the same time, the basic goal of the developed program centers around eliminating the gap between knowledge due to the reduction of the amount of brain drain with the use of specially created innovation centers based on the best practices of countries that effectively overcome such problems (UNESCO, n.d.).

International cooperation of Warsaw University of Technology with other tertiary educational institutions takes place within the framework of the organization and support of the Center for International Cooperation. This center aims to strengthen academic and research cooperation between Warsaw University of Technology and other tertiary educational institutions and industrial partners from around the world. In addition, the key functions of this unit include: coordination of European research programs; ensuring the participation of teachers and students in international grants, scholarships and internships; coordination of participation in international educational programs (curricula); reception of delegations and visits of representatives of international academies, etc. (Warsaw University of Technology, n.d.).

\section{Discussion}

A study of development trends of international cooperation among tertiary educational institutions has shown a high level of cooperation between them. It has been established that the basic areas of international cooperation among tertiary educational institutions include: the development of international mobility in the framework of the exchange not only of students, but also of educators, researchers, and administrative staff; joint teaching and investigation activities; research cooperation.

The results of the study conducted make it possible to note that the basic principles of international cooperation between tertiary educational institutions are regulated by the Agreement of Cooperation between Universities, a memorandum of understanding concluded for a maximum of 3 years between tertiary educational institutions, bilateral agreements between tertiary educational institutions. 
Studies prove that European Commission has developed and implemented the Erasmus + and Horizon 2020 program in order to ensure an appropriate level of international cooperation between tertiary educational institutions. For instance, the Erasmus + program assumes regional cooperation between tertiary educational institutions of European Union member countries and universities in other countries of the world in the context of helping to reduce poverty and increase inclusive education. The Erasmus + program also provides support for the curriculum of tertiary educational institutions, which is necessary to improve the quality of teaching and to achieve an appropriate level of educational process. In order to ensure the internationalization of tertiary education, the Bologna Process has been developed and put into practice, the basic goal of which centers around achieving coherence between systems of tertiary education in 48 European countries.

Studying the practice of promoting international cooperation between universities in European Union makes it possible to note the following key aspects of cooperation, such as: attracting talented individuals to the tertiary education structure of European Union member states; support for innovation and creation of job opportunities through a skills mobility system; support for the policy of European Union, in particular in the field of enlargement, international development, international migration, intercultural dialogue.

The study has examined numerous international networks, university wide projects and platforms that were formed as a result of international cooperation between tertiary educational institutions, in particular: ACCESS, CALIE, European University Association, Eutopia, Inspireurope, International Association of Universities, MIRAI, Nordic Association of University Administrators, Nordic Centre India, Nordic Centre Fudan University, Nordic Institute of Asian Studies, SGroup European Universities' Network, SANORD, Scholars at risk, SASUF.

According to the results of data processing by the European University Association (n.d.), it has been established that tertiary educational institutions of Ukraine also take an active part in the system of international cooperation. Thus, 26 tertiary educational institutions of Ukraine are Individual Full Members and Individual Associate Members of the European University Association.

Trends in international cooperation in higher educational institutions are determined by economic, social and cultural changes. Changes in student mobility, curricula, distance education, growth in the number of students continue to determine trends in cooperation (Chetro-Szivos, 2010). Growing awareness of the important role of international cooperation in higher education plays an important role in building national capacity and strengthening the capacity for intercultural cooperation. Scientists believe that knowledge sharing (Chetro-Szivos, 2010) affects socio-economic development through intellectual population growth. Globalization, the transition to a knowledge economy and the internationalization of educational institutions necessitate international cooperation (Chetro-Szivos, 2010).

Cooperation in the sphere of education is not new. There is a history of exchange of students, professors and knowledge. EU countries are constantly working to reduce inequalities and imbalances in the skills of the labor force and the labor market, which leads to the growth of examples of cooperation (Donchenko, 2015).

International cooperation has also been a solution to the problem of independent assessment of knowledge (Chetro-Szivos, 2010). Knowledge transfer and exchange, partner selection and funding encourage this type of cooperation. Cultural differences are an advantage in collaboration (Franco \& Pinho, 2019).

International cooperation promotes peace and intercultural understanding, human resource development, research and innovation (Donchenko, 2015). Exchange of experience in educational activities means mutual understanding between representatives of different countries anywhere in the world. This means that the principle of social constructivism is realized through education and here participants together form a narrow culture of common objects (Kerimbayev et al., 2017).

\section{Conclusion}

Therefore, according to the results of processing the theoretical and practical aspects of international cooperation among tertiary educational institutions in the framework of determining current trends and future prospects for the development of such relations:

1) the features of the directions of international cooperation among tertiary educational institutions have been clarified;

2) the dynamics of students' mobility from abroad, enrolled in tertiary education, as well as the level of mobility among students in the areas of the corresponding level of tertiary education in such countries, as Germany, the Czech Republic and Sweden have been considered and analyzed; 
3) the key aspects of international cooperation among tertiary educational institutions of Germany (according to data of the German Rectors' Conference), Sweden (on the example of the University of Gothenburg) and Ukraine (according to data of the European University Association (n.d.)) have been investigated.

The results of the investigation conducted have proven that international cooperation between tertiary educational institutions makes it possible to: strengthen the institutional academic and administrative capacity of tertiary educational institutions; improve the quality of tertiary education; increase the efficiency of the system of tertiary education; improve the quality and increase the amount of human capital; increase the prestige of tertiary educational institutions in the international arena; expand the participation of students and teachers in the processes of international exchange or in joint educational and research projects; improve students' performance; raise intercultural awareness.

\section{References}

Arcella, F., Mincer-Daszkiewicz, J., \& Ravaioli, S. (2009). Web-services for Exchange of Data on Cooperation and Mobility between Higher Education Institutions. Retrieved from https://pdfs.semanticscholar.org/5fc5/5c6ef368815f07214451b84a96e78c803fba.pdf?_ga=2.212824276.139474 813.1595796953-117326506.1595796953

Association of Accredited Public Policy Advocates to the European Union. (2019). Agreement of Cooperation between Universities. Retrieved from http://www.aalep.eu/agreement-cooperation-between-universities

Beerkens, E. (2018). International Consortia of Higher Education Institutions. Encyclopedia of International Higher Education Systems and Institutions. Dordrecht, Germany: Springer. https://doi.org/10.1007/978-94-017-9553-1_278-1

Bonilla, K., Salles-Filho, S., \& Bin, A. (2018). Building Science, Technology, and Research Capacity in Developing Countries: Evidence from student mobility and international cooperation between Korea and Guatemala. STI Policy Review, 9(1), 99-132.

Central European University. (n.d.). Coopeation Agreements. Retrieved from https://www.ceu.edu/partnerships/cooperation

Chetro-Szivos, J. (2010). Cross-border Tertiary Education: The Challenges and Opportunities for Intercultural Understanding. Journal of Intercultural Management, 2(1), 5-22.

Donchenko, V. (2015). University international cooperation as a means for regional integration and development. EURINT, Centre for European Studies, Alexandru Ioan Cuza University, 2, 131-140.

European Commission. (n.d.a). Education and training: About higher education policy. Retrieved from https://ec.europa.eu/education/policies/higher-education/about-higher-education-policy_en

European Commission. (n. d.b). Education and training: European higher education in the world. Retrieved from https://ec.europa.eu/education/policies/international-cooperation/european-higher-education-world_en

European Commission. (n.d.c). Education and training: International cooperation and policy dialogue. Retrieved from

https://ec.europa.eu/education/policies/international-cooperation/international-cooperation-and-policy-dialogue -en

European Commission. (n.d.d). Education and training: The Bologna Process and the European Higher Education Area. Retrieved from https://ec.europa.eu/education/policies/higher-education/bologna-process-and-european-higher-education-area_ en

European University Association. (n.d.). Member directory. Retrieved from https://eua.eu/about/member-directory.html

Eurostat. (n.d.). Retrieved from https://ec.europa.eu/eurostat/

Franco, M., \& Pinho, C. (2019). A case study about cooperation between University Research Centres: Knowledge transfer. Journal of Innovation \& Knowledge, 4(1), 62-69. https://doi.org/10.1016/j.jik.2018.03.003

Galan, Y., Yarmak, O., Kyselytsia, O, Paliichuk, Y., Moroz, O., \& Tsybanyuk, O. (2018). Monitoring the physical condition of 13-year-old schoolchildrenduring the process of physical education. Journal of Physical Education and Sport, 18(2), 663-669. 
$\begin{array}{lllll}\text { International } & \text { university } & \text { partnerships. } & \text { (n.d.). } & \text { Retrieved }\end{array}$ https://www.internationale-hochschulkooperationen.de/en/international-university-partnerships.html

Kerimbayev, N., Kultan, J., Abdykarimova, S., \& Akramova, A. (2017). LMS Moodle: Distance international education in cooperation of higher education institutions of different countries. Education and Inforrmation Technologies, 22, 2125-2139. https://doi.org/10.1007/s10639-016-9534-5

King, K. (2009). Higher Education and International Cooperation: The role of academic collaboration in the developing world. In D. Stephens (Ed.), Higher Education and International Capacity Building: Twenty Five Years of Higher Education Links, 33-49. Oxford, UK: Symposium Books.

Obolenska, T., \& Tsyrkun, O. (2016). Conceptual approaches to international cooperation between higher education institutions. International Economic Policy, 2, 40-58.

Oganesyan, A. A. (2017). New forms of university cooperation: international network universities. RUDN Journal of Economics, 25(3), 354-366. https://doi.org /10.22363/2313-2329-2017-25-3-354-366

Orosz, K., \& Craciun, D. (2019). Dearth of evidence of value of international cooperation. University World News. Retrieved from https://www.universityworldnews.com/post.php?story=20190204144538245

Palacký University Olomouc. (n.d.). International Cooperation. Retrieved from https://ftk.upol.cz/en/about/international-cooperation/

Polish National Agency for Academic Exchange. (n.d.). International Academic Partnerships. Retrieved from https://nawa.gov.pl/en/institutions/international-academic-partnerships

Quacquarelli Symonds (QS). (2019). Why are International Collaborations so Important for Universities? Retrieved from: https://www.qs.com/why-are-international-collaborations-so-important-for-universities/

Skvorcovs, A., Titareva, T., \& Igors, G. (2018). The development trends of the main drivers for attracting students into the tertiary education sector in Latvia-distance learning and internationalization. 4th International Conference on Higher Education Advances (HEAd'18), 461-469. Universitat Politecnica de Val'encia, Val'encia. http://doi.org/10.4995/HEAd18.2018.8013

UNESCO. (n.d.). Inter-University cooperation. $\quad$ Retrieved from http://www.unesco.org/en/university-twinning-and-networking/inter-university-cooperation//

University of Gothenburg. (n.d.) International networks. Retrieved from https://www.gu.se/english/about_the_university/cooperation/international_cooperation/international-networks

Warsaw University of Technology. (n.d.). The Centre for International Cooperation. Retrieved from https://www.pw.edu.pl/engpw/International3/The-Centre-for-International-Cooperation

Wolf, F. M. (1986). Meta-analysis: Quantitative methods for research synthesis. Newbury Park, CA: Sage. https://doi.org/10.4135/9781412984980 